\title{
Sifat Fisik dan Organoleptik Mie Kering dengan Penambahan Tepung Ubi Jalar dan Tepung Kedelai
}

\section{Physical and organoleptic properties dry noodles with the addition of sweet potato and soy flour}

\author{
Risma Uli Situngkir ${ }^{1}, Z^{2}$ ta Letviany Sarungallo ${ }^{1 *}$, Rosalia Sira Sarungallo ${ }^{2}$ \\ ${ }^{1}$ Prodi Teknologi Hasil Pertanian, Fakultas Teknologi Pertanian, Universitas Papua. Jl. Gunung Salju, Amban, \\ Manokwari-98314, Papua Barat. \\ ${ }^{2}$ Prodi Teknik Kimia, Fakultas Teknik, Universitas Kristen Indonesia Paulus. Jl. Perintis Kemerdekaan \\ Km. 13, Daya, Makassar-90235, Sulawesi Selatan \\ *Email korespondensi: zlsarungallo@yahoo.com
}

\begin{abstract}
The objectives of the research were to determine physicals and organoleptics properties of noodles with added sweet potato and soy flour. Noodles were prepared with 100\% wheat flour (control), $10 \%$ sweetpotatoe flour, and combination of sweetpotatoe and soy flour with ratio 10\%:5\% and 10\%:10\%. Analysis noodle include of physics properties (colour and cooking loss) and organoleptics atribute (colour, flavour, overall, tenderness and stickiness) were compared with control noodles. The result showed that 10\% sweetpotatoe contributed orange colour and increased colour, flavour, and overall acceptability with no different tenderness and stickiness acceptability with control, but increased cooking loss. While addition of soy flour increased cooking loss, reduced lightness and sensory properties of noodle.
\end{abstract}

Keywords: sweet potato, soy flour, noodle, physics properties, organoleptics properties

\begin{abstract}
Abstrak
Penelitian ini bertujuan untuk menentukan sifat fisik dan organoleptik mie yang terbuat dari tepung ubi jalar dan dan tepung kedelai. Mie terbuat dari $100 \%$ tepung terigu (kontrol), tepung ubi jalar 10\%, dan kombinasi tepung ubi jalar dan tepung kedelai dengan rasio 10\%: 5\% dan 10\%:10\%. Analisis mie termasuk sifat fisika (warna dan kehilangan memasak) dan uji organoleptik (warna, rasa, keseluruhan, kelembutan dan lengket) dibandingkan dengan mie kontrol. Hasil penelitian ini menunjukkan bahwa penambahan $10 \%$ ubi jalar memberikan kontribusi warna oranye dan peningkatan warna, rasa, dan penerimaan secara keseluruhan tanpa kelembutan yang berbeda dan akseptabilitas lengket dengan kontrol, tetapi nilai cooking loss meningkat. Sementara penambahan tepung kedelai dalam formula dapat meningkatkan cooking loss, mengurangi kecerahan warna dan sifat organoleptik mie.
\end{abstract}

Kata kunci: ubi jalar, tepung kedelai, mie, sifat fisik, sifat organoleptik

\section{PENDAHULUAN}

Mie merupakan salah satu jenis makanan sehari-hari yang digemari oleh sebagian besar masyarakat Indonesia dan umumnya dibuat dari tepung terigu. Selain mudah ditemui, mie sangat praktis penggunaannya untuk diolah menjadi berbagai jenis masakan. Peningkatan konsumsi mie baik itu mie kering, mie basah ataupun mie instan akan diikuti dengan peningkatan kebutuhan bahan bakunya. Indonesia masih mengimpor biji gandum sebagai bahan pembuatan tepung terigu (Mulyadi dkk., 2013). Salah satu upaya mengurangi ketergantungan kebutuhan tepung terigu adalah memanfaatkan bahan pangan lokal seperti tepung ubi jalar kuning sebagai substitusi bahan baku mie. Alternatif penggunaan bahan baku pensubstitusi terigu seperti tepung ubi jalar dan kedelai dapat meningkatkan mutu nilai gizi berbagai produk mie seperti sumber vitamin A seperti tepung ubi jalar (Juanda dan Cahyono, 2000) dan protein 
seperti tepung kedelai (Widaningrum dkk., 2005). Kedua bahan tersebut mudah diperoleh dan berpotensi meningkatkan sifat fungsional spesifik pada pasta.

Ubi jalar merupakan salah satu komoditas bahan makanan pokok yang dapat diolah menjadi tepung ubi jalar. Tepung ubi jalar merupakan bahan lokal yang memiliki kandungan gizi yang tidak kalah penting dengan tepung terigu. Ubi jalar memiliki peran yang cukup penting dalam perbaikan gizi di Indonesia yaitu sebagai salah satu sumber karbohidrat, yang menghasilkan kalori 123 kalori per 100 gram bahan, juga merupakan sumber vitamin $\mathrm{A}$, vitamin $\mathrm{C}$, serta mineral utama seperti kalsium dan besi pada varietas berdaging merah (Juanda dan Cahyono, 2000). Sedangkan kedelai yang mengandung protein tinggi yaitu sekitar 30$35 \%$ (Widaningrum dkk., 2005), merupakan salah satu sumber protein nabati. Penggunaan tepung ubijalar dan tepung kedelai dalam pembuatan mie, merupakan upaya diversifikasi pangan untuk meningkatkan nilai gizi masyarakat. Perbandingan konsentrasi tepung ubi jalar dan tepung kedelai akan mempengaruhi sifat fisik dan organoleptik mie yang dihasilkan. Penelitian ini bertujuan untuk menentukan sifat fisik dan organoleptik mie yang terbuat dari tepung ubi jalar dan dan tepung kedelai.

\section{METODOLOGI}

\section{Bahan dan alat}

Bahan yang digunakan dalam pembuatan mie adalah tepung terigu serbaguna (Bogasari, Indofood), ubi jalar dengan daging umbi berwarna jingga, kacang kedelai, telur ayam, asam sitrat, garam dapur dan plastik kemasan.

Peralatan yang digunakan adalah pisau, talenan, loyang, ayakan, noodle machine (Siraitodai Futhuu, Tokyo, Jepang), timbangan kasar, timbangan analitik, chromameter (Minolta CR-200 JS0030, Jepang), water bath, oven, lemari pendingin, kompor, dan peralatan gelas lainnya.

\section{Metode penelitian}

Metode yang digunakan dalam penelitian ini adalah metode eksperimen menggunakan Rancangan Acak Lengkap (RAL) yang terdiri dari empat perlakuan, yakni perlakuan formulasi mie F0 (100\% tepung terigu), F1 (0\% tepung kedelai dengan 10\% tepung ubi jalar), F3 (5\% tepung kedelai dengan $10 \%$ tepung ubi jalar), dan F4 (10\% tepung kedelai dengan $10 \%$ tepung ubi jalar). Masing-masing perlakuan tersebut diulang sebanyak dua kali.

\section{Pembuatan Ubi Jalar}

Umbi ubi jalar disiapkan dalam bentuk tepung. Umbi dicuci, dikupas dan diiris-iris setebal 5-6 mm. Irisan direndam dalam larutan asam sitrat $1 \%$ selama \pm 30 menit. Setelah pengupasan sampai pemotongan, irisan ubi jalar dikeringkan pada suhu $60^{\circ} \mathrm{C}$ selama 4 jam sampai bahan cukup kering untuk digiling. Selanjutnya ubi jalar kering digiling, diayak, dikemas plastik dan di simpan pada suhu -12 sampai $-14^{\circ} \mathrm{C}$ sampai digunakan.

\section{PembuatanTepung Kedelai}

Pembuatan tepung kedelai menggunakan cara yang dilaporkan Widaningrum dkk. (2005) dengan sedikit modifikasi. Biji kedelai disortasi untuk memisahkan buah yang cacat atau rusak, kemudian dilakukan pencucian dan perendaman air panas selama 10 menit, dan dilakukan pengupasan kulit. Biji kedelai dikeringkan dengan oven pada suhu $60^{\circ} \mathrm{C}$ selama 4 jam, atau sampai bahan cukup kering untuk digiling. Selanjutnya biji kedelai digiling dan diayak, setelah itu dikemas dalam plastik dan disimpan pada suhu -12 sampai $-14^{\circ} \mathrm{C}$ sampai digunakan.

\section{Persiapan Tepung Kedelai}

Mie untuk kontrol (sebagai pembanding) disiapkan dari bahan-bahan dasar sesuai formulasi untuk pasta yaitu tepung gandum (11\% protein, tepung dasar) $100 \%$, air, telur dan garam (Matz,1991). Komposisi bahanbahan mie yang digunakan dalam penelitian ini disajikan dalam Tabel 1.

Tabel 1. Formula Bahan-bahan dalam Pembuatan Mie

\begin{tabular}{cccccc}
\hline Pelakuan & Tep. Terigu & Tep. Ubi jalar & Tep. Kedelai & Telur & Air \\
\hline F0 & $500 \mathrm{gr}$ & - & - & 1 butir & $150 \mathrm{ml}$ \\
F1 & $450 \mathrm{gr}$ & $50 \mathrm{gr}$ & - & 1 butir & $150 \mathrm{ml}$ \\
F2 & $425 \mathrm{gr}$ & $50 \mathrm{gr}$ & $25 \mathrm{gr}$ & 1 butir & $150 \mathrm{ml}$ \\
F3 & $405 \mathrm{gr}$ & $50 \mathrm{gr}$ & $45 \mathrm{gr}$ & $1 \mathrm{butir}$ & $150 \mathrm{ml}$ \\
\hline
\end{tabular}




\section{Persiapan Adonan Mie}

Adonan mie disiapkan dengan menimbang $500 \mathrm{gr}$ tepung. Semua bahan kering (tepung terigu, tepung ubi jalar dan garam) dicampur dan diayak untuk menghasilkan campuran yang seragam. Campuran bahan-bahan ditempatkan dalam loyang pencampur pada alat noodle machine kemudian dicampur dengan dough-hook selama 1 menit. Air dan telur dimasukan dan pencampuran dilakukan selama 15 menit, atau sampai adonan kaku. Adonan kemudian dibentuk lembaran dengan rolling pin setebal $\pm 1,5 \mathrm{~cm}$. Lembaran adonan dilewatkan pada hand operated machine (pada alat noodle machine) dan direduksi sampai setebal $1,5 \mathrm{~cm}$. Adonan dipotong selebar $5 \mathrm{~mm}$, dan dikeringkan dalam oven pada suhu $50-60^{\circ} \mathrm{C}$ selama 4 jam (Astawan, 2003). Selanjutnya mie kering didinginkan pada suhu kamar, dikemas pada plastik dan simpan pada suhu $12^{\circ}$ sampai $-14^{\circ} \mathrm{C}$ sampai diuji.

\section{Pengukuran Waktu Pemasakan Optimum dan Cooking loss}

Metode yang digunakan merupakan modifikasi dari Rasper dan de Man, (1980). Penentuan waktu pemasakan optimum, diawali dengan pemotongan mie $(5 \mathrm{~g})$ sepanjang $5 \mathrm{~cm}$ dan dimasak dalam $150 \mathrm{ml}$ air mendidih di dalam gelas kimia. Gelas kimia ditutup dengan aluminium foil untuk mengurangi penguapan air. Waktu masak optimum ditentukan dengan cara yaitu selama pemasakan, setiap 30 menit potongan mie diangkat dan dipres diantara dua gelas arloji dan diamati secara visual. Waktu optimum dicapai apabila warna putih pada bagian tengah mie tidak tampak lagi. Mie yang telah masak dikeringkan dengan corong Buchner.

Pengukuran cooking loss dimulai dengan merebus 5 gr mie kering dalam $150 \mathrm{ml}$ air dalam gelas kimia. Setelah mencapai waktu masak optimum, mie ditiris selam 5 menit, timbang dan keringkan dalam oven pada suhu $105^{\circ} \mathrm{C}$ sampai dicapai berat konstan. Sementara itu dilakukan pengukuran kadar air mie kering dengan oven pada suhu $105^{\circ} \mathrm{C}$.
Kehilangan padatan akibat pemasakan ditentukan dengan membagi selisih berat kering awal dan berat kering akir dengan berat kering awal.

\section{Pengujian Sifat Organoleptik}

Pengujian sifat organoleptik mie yang dihasilkan didasarkan pada uji hedonik dan uji penjenjangan (Setyaningsih dkk., 2010). Sampel mie dipotong $6 \mathrm{~cm}$ dan 60-80 g dimasak secara acak dalam 1,5 L air mendidih selama 11 menit. Mie didinginkan dalam tirisan dibawah air mengalir selama 1 menit sebelum disajikan. Sampel ditampilkan sendiri-sendiri secara acak dalam mangkuk plastik berkapasitas $60 \mathrm{ml}$.

Sampel mie yang telah matang dievaluasi terhadap warna, flavor dan penampakan keseluruhan, serta intensitas dari kelengketan dan kehalusan. Sampel dievaluasi pada 7 skala dengan 1 "sangat tidak disukai " dan 7 "sangat disukai" untuk tes hedonik. Evaluasi kehalusan dengan kisaran 1 "sangat keras" dan 7 "sangat halus", dan untuk kelengketan dengan kisaran 1 "sangat lengket" dan 7 "sangat tidak lengket" (Setyaningsih dkk., 2010).

\section{Analisis Data}

Data yang diperoleh dari penelitian ini dianalisis secara statistik menggunakan analisis ragam, dan jika berbeda nyata maka akan dilanjutkan dengan analisis DMRT (Duncan's Multiple Range Test) menggunakan Program SPSS (Statistical Product and Service Solutions) seri 17.0.

\section{HASIL DAN PEMBAHASAN}

\section{Sifat Fisik Mie Kering}

Warna asli produk mie kering akan sangat mempengaruhi daya beli konsumen. Hasil pengukuran warna (Tabel 2) menunjukkan bahwa penambahan tepung ubi jalar dan kedelai berpengaruh terhadap nilai $\mathrm{L}$ (kecerahan), $a_{L}$ (Kemerahan) dan $b_{L}$ (kuning) dari warna mie yang dihasilkan. 
Tabel 2. Hasil pengukuran terhadap intensitas warna mie kering dari tepung ubijalar dan tepung kedelai

\begin{tabular}{lcccc}
\hline \multirow{2}{*}{ Perlakuan* } & \multicolumn{3}{c}{ Warna } & \multirow{2}{*}{ Cooking loss } \\
\cline { 2 - 4 } & $\mathrm{L}^{*}$ & $\mathrm{a}^{*}$ & $\mathrm{~b}^{*}$ & \\
\hline F0 (Tepung Terigu 100\%) & $7,029^{\mathrm{d}}$ & $70,837^{\mathrm{a}}$ & $52,793^{\mathrm{a}}$ & $6,78^{\mathrm{a}}$ \\
F1 (0\% TK + 10\% TUJ) & $6,231^{\mathrm{c}}$ & $89,152^{\mathrm{b}}$ & $63,972^{\mathrm{b}}$ & $11,8^{\mathrm{b}}$ \\
F2 (5\% TK + 10\% TUJ) & $6,193^{\mathrm{ab}}$ & $75,339^{\mathrm{c}}$ & $58,632^{\mathrm{c}}$ & $12,66^{\mathrm{c}}$ \\
F3 (10\% TK + 10\% TUJ) & $6,165^{\mathrm{a}}$ & $74,713^{\text {cd }}$ & $56.236^{\mathrm{cd}}$ & $14,08^{\mathrm{d}}$ \\
\hline
\end{tabular}

Ket. : $\mathrm{TK}=$ tepung Kedelai, $\mathrm{TUJ}=$ tepung ubi jalar

$\mathrm{L}^{*}=$ terang, nilai meningkat warna semakin terang

$a^{*}$ dan $b^{*}=$ merah dan kuning, tiap nilai meningkat dengan meningkatnya intensitas warna

Huruf yang berbeda di sebelah angka pada kolom yang sama menunjukan perbedaan nyata $(\mathrm{P}<0,05)$

Data pada Tabel 2 menunjukkan bahwa nilai $L$ (kecerahan) berkisar 6,1-7,03, dimana nilai L mie kontrol paling tinggi dan cenderung menurun dengan penambahan tepung ubi jalar tepung kedelai. Hasil analisis ragam yang dilakukan menunjukkan bahwa penambahan tepung ubi jalar dan kedelai yang diberikan berpengaruh sangat nyata terhadap nilai kecerahan (Nilai L) mie kering. Hasil uji lanjut Duncan pada tingkat kepercayaan 95\% menunjukkan bahwa perlakuan penambahan tepung ubi jalar dan kedelai berpengaruh nyata terhadap nilai $\mathrm{L}$ mie kering yang dihasilkan. Perlakuan penambahan tepung kedelai pada konsentrasi $5 \%$ dan $10 \%$ tepung kedelai dengan $10 \%$ tepung ubi jalar menghasilkan warna mie yang lebih gelap. Hal ini terjadi akibat peningkatan konsentrasi tepung kedelai karena secara alami berwarna kecoklatan sehingga menghasilkan bintik-bintik berwana coklat muda pada mie, sehingga cenderung menurunkan kecerahan warna mie. Penurunan nilai kecerahan mie ini diduga karena adanya pigmen karotenoid pada tepung ubi jalar dan kandungan protein yang cukup tinggi pada tepung kedelai. Hal ini didukung oleh Collins dan Pangloli (1997) melaporkan bahwa penambahan ubi jalar menyebabkan mie memiliki nilai kecerahan yang lebih rendah dan menghasilkan pasta lebih gelap yang diperlihatkan oleh sampel $0 \%$ kedelai bebas lemak. Warna kecerahan mie cenderung menurun dengan meningkatnya konsentrasi kedelai. Kecenderungan yang sama juga dilaporkan Hidayat dkk., (2019) bahwa penambahan tepung kacang hijau menyebabkan perubahan warna pada rolled cookies. Pada saaat pemanggangan, karbohidrat dan protein nabati pada kacang hijau akan menyebabkan reaksi maillard yang akan mempengaruhi warna rolled cookies.
Data pada Tabel 2, memperlihatkan bahwa nilai a (warna merah) pada mie berkisar 70,8-89,1. Nilai a terendah dimiliki perlakuan mie kontrol, dan cenderung meningkat dengan penambahan tepung ubi jalar, dan cenderung menurun dengan penambahan kadar tepung kedelai. Hasil analisis ragam yang dilakukan menunjukkan bahwa penambahan tepung ubi jalar dan kedelai yang diberikan berpengaruh sangat nyata terhadap nilai kemerahan (Nilai a) mie kering. Hasil uji lanjut Duncan pada tingkat kepercayaan 95\% menunjukkan bahwa nilai a berbeda nyata pada setiap perlakuan kecuali perlakuan pada F2 (5\% tepung kedelai) dan F3 (10\% tepung kedelai) tidak menunjukan perbedaan nyata. Hal ini diduga disebabkan karena tepung ubi jalar yang digunakan berwarna kuning muda sehingga penambahan kosentrasi tepung kedelai menurunkan intensitas warna merah pada mie. Hal yang sama dilaporkan oleh Collins dan Pangloli (1997) bahwa nilai merah (Hunter $a_{L}$ ) mie meningkat dengan penambahan tepung ubi jalar, peningkatan tepung kedelai bebas lemak menghasilkan merah yang lebih rendah.

Nilai b (warna kuning) pada mie yang dihasilkan bervariasi antar perlakuan berkisar 52,8-3,9 (Tabel 2). Tingkat warna kuning terendah dimiliki mie F0 (100\% terigu), dan yang tertinggi dimiliki F1 (10\% tepung ubi jalar). Hasil analisis ragam yang dilakukan menunjukkan bahwa penambahan tepung ubijalar dan tepung kedelai berpengaruh nyata terhadap tingkat warna kuning (Nilai b) mie kering yang dihasilkan. Hasil uji lanjut Duncan pada tingkat kepercayaan $95 \%$ menunjukkan bahwa nilai $b$ berbeda nyata pada setiap perlakuan, kecuali pada perlakuan dengan penambahan 5\% dan 10\% tepung kedelai tidak memperlihatkan perbedaan. Nilai $\mathrm{b}$ cenderung meningkat dengan peningkatan kadar tepung 
ubi jalar mempunyai intensitas warna kuning yang cenderung lebih rendah dari mie kontrol. Hal ini dapat disebabkan tepung ubi jalar yang digunakan berwarna kuning kemerahan (jingga) sehingga mie yang dihasilkan berwarna kuning, dan meningkatkan intensitas warna kuning pada mie. Sedangkan warna tepung kedelai yang digunakan dalam pembuatan mie adalah kuning muda sehingga peningkatan konsentrasi tepung kedelai menurunkan nilai kuning sehingga menjadi lebih rendah. Collins dan Pongloli (1997) melaporkan bahwa nilai kuning (Hunter $b_{L}$ ) meningkat dengan penambahan ubi jalar diperlihatkan pada 0\% kedelai bebas lemak, dan peningkatan kedelai bebas lemak menghasilkan nilai Hunter $b_{L}$ yang lebih rendah. Nielsen dkk., (1980) juga melaporkan bahwa pasta yang difortifikasi dengan pea powder mempunyai warna kuning yang diinginkan, ditambahkan pula bahwa warna kuning cerah pada mie disukai oleh konsumen.

\section{Cooking loss Mie Kering}

Cooking loss atau kehilangan padatan akibat pemasakan dinyatakan sebagai banyaknya padatan terlarut yang keluar dari dalam mie kering, yang keluar dan terlarut ke dalam air selama proses pemasakan. Jika nilai cooking loss rendah akan menghasilkan mie yang lebih baik. Data pada Gambar 1, memperlihatkan bahwa cooking loss mie kering yang dihasilkan bervariasi antar perlakuan yang berkisar antara 6,78-14,08\%, dimana nilai terendah dimiliki oleh mie kontrol (F0), dan cenderung meningkat dengan penambahan tepung ubi jalar dan kedelai.

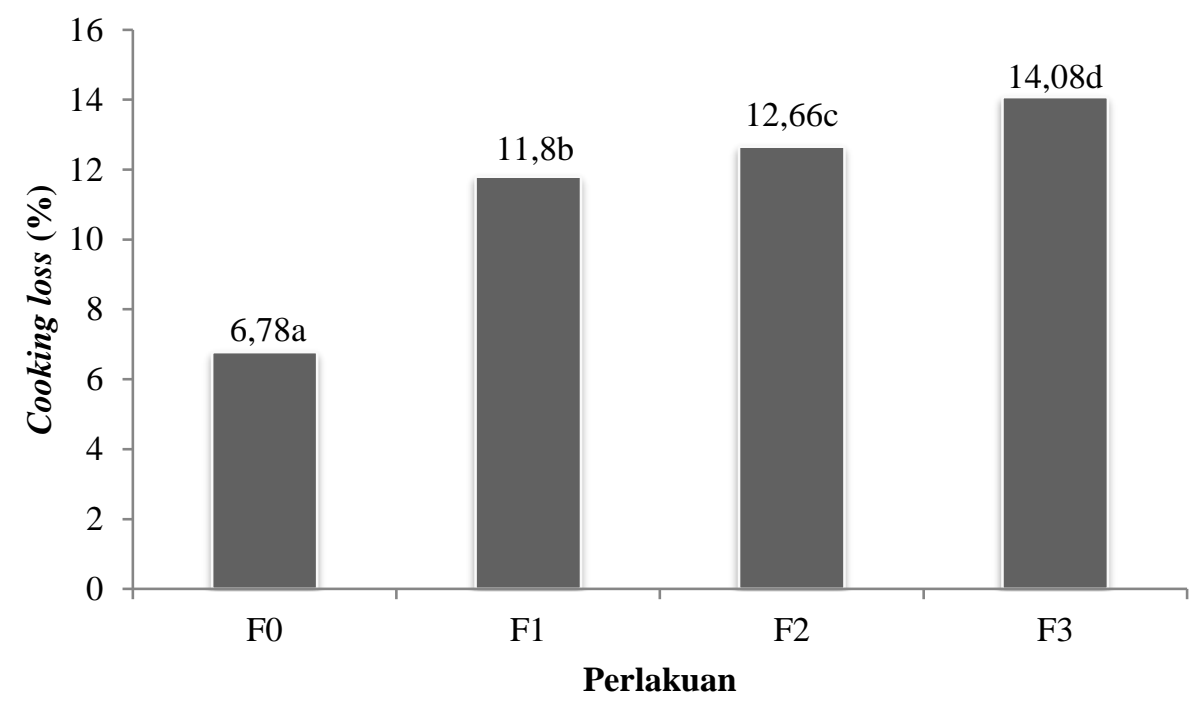

Ket.:

F0 $=$ Tepung Terigu 100\%; F1=10\%Tepung Ubijalar); F2=5\% Tepung Kedelai $+10 \%$ Tepung Ubijalar; F3 (10\% Tepung Kedelai $+10 \%$ Tepung Ubijalar)

*) huruf yang berbeda di sebelah angka menunjukan perbedaan nyata $(\mathrm{P}<0,05)$ pada setiap perlakuan

Gambar 1. Cooking loss mie kering dari tepung ubijalar dan tepung kedelai

Hasil analisis ragam (Gambar 1) memperlihatkan bahwa perlakuan penambahan tepung ubi jalar dan kedelai yang diberikan berpengaruh sangat nyata terhadap cooking loss mie kering. Hasil uji lanjut Duncan pada tingkat kepercayaan $95 \%$ juga menunjukkan bahwa cooking loss berbeda nyata pada setiap perlakuan. Penambahan tepung ubi jalar dan kedelai cenderung meningkatkan kehilangan padatan akibat pemasakan (cooking loss) dari mie kering yang dihasilkan, dan cenderung lebih menurun lagi dengan peningkatan level tepung kedelai.

Meningkatnya kadar cooking loss mie dengan penambahan tepung ubi jalar diduga disebabkan oleh sedikitnya jumlah fraksi protein bahan yang dapat membentuk jaringan yang kompak serta elastis, yang dapat menahan pembengkakan adonan serta larutnya komponen-komponen granula pati (Pagani, 1985), dimana komponen tersebut tidak tersedia dalam tepung ubi jalar. Gluten yang 
berasal dari gandum merupakan bahan yang utama dalam fungsinya sebagai bahan pengikat pada pembentukan adonan. Menurut Metres dkk., (1988) pati mie bebas gluten, memiliki tekstur yang lebih lunak, karena itu pati lebih berfungsi sebagai jaringan (network) untuk mempertahankan struktur selama pemasakan. Ditambahkan pula bahwa pengembangan jaringan selama pemasakan akibat hidrasi bagian-bagian amorphous. Pengrusakan jaringan tersebut menyebabkan amolosa dilepaskan dan meningkatkan cooking loss (Metres dkk., 1988).

Peningkatan konsentrasi tepung kedelai menyebabkan cooking loss mie kering cenderung meningkat, diperlihatkan pada level $5 \%$ dan $10 \%$ tepung kedelai dengan $10 \%$ tepung ubi jalar, yang masing-masing menurun 1,87 kali dan 2 kali dari mie control (F0). Collins dan Pangloli (1997) melaporkan bahwa cooking loss mie pada $10 \%$ kedelai bebas lemak 1,8 kali lebih mengalami kehilangan dari kontrol, ditambahkan pula bahwa cooking loss maksimum diterima adalah $8 \%$. Sementara itu, Widoningrum dkk., (2005) melaporkan penambahan tepung kedelai dari $10 \%$ dalam mie basah campuran terigu $(70 \%)$ dan tepung garut (20\%) memiliki cooking loss sekitar 12,6\%. Menurut Pagani (1985), adanya koagulasi dari sejumlah protein dalam bahan juga turut mempengaruhi tingginya cooking loss dengan cara menghambat repolimerisasi ikatan dalam pati setelah gelatinisasi. Muhandri (2012) menjelaskan bahwa karakteristik mutu mie berbahan tepung non terigu terbaik dapat dicapai bila adonan tepung mengalami gelatinisasi, tekanan dan pemotongan adonan cukup.

\section{Sifat organoleptic mie kering}

Pengujian sensori dimaksud untuk mengetahui tingkat penerimaan panelis terhadap mutu produk yang dihasilkan (Setyaningsih dkk., 2010). Karakteristik organoleptik mie kering, yang dibuat dari tepung ubi jalar dan tepung kedelai yang dihasilkan diuji terhadap warna, flavor, keseluruhan, serta intensitas tekstur terhadap kehalusan dan kelengketan (Tabel 3).

Tabel 3. Rata-rata penilaian perimaan sensori panelis terhadap mie kering dengan penambahan tepung ubi jalar dan tepung kedelai.

\begin{tabular}{|c|c|c|c|c|c|}
\hline \multirow{2}{*}{ Perlakuan } & \multicolumn{3}{|c|}{ Penerimaan* } & \multicolumn{2}{|c|}{ Intensitas tekstur } \\
\hline & Warna & Flavor & Keseluruhan & Kehalusan** & Kelengketan*** \\
\hline F0 (Tepung Terigu 100\%) & $3,9^{\mathrm{a}}$ & $6,00^{\mathrm{bc}}$ & $5,14^{\mathrm{ab}}$ & $6,0^{\mathrm{bc}}$ & $4,30^{\mathrm{a}}$ \\
\hline F1 (0\% TK + 10\% TUJ) & $6,4^{b}$ & $6,14^{\mathrm{bc}}$ & $6,40^{\mathrm{c}}$ & $5,7^{\mathrm{bc}}$ & $5,00^{\mathrm{a}}$ \\
\hline $\mathrm{F} 2(5 \% \mathrm{TK}+10 \% \mathrm{TUJ})$ & $4,3^{\mathrm{a}}$ & $5,14^{\mathrm{ab}}$ & $5,00^{\mathrm{ab}}$ & $4,7^{\mathrm{ab}}$ & $5,14^{\mathrm{a}}$ \\
\hline F3 (10\% TK + 10\% TUJ) & $4,0^{\mathrm{a}}$ & $4,86^{\mathrm{a}}$ & $4,57^{\mathrm{a}}$ & $3,7^{\mathrm{a}}$ & $5,28^{\mathrm{a}}$ \\
\hline
\end{tabular}

Keterangan:

*Nilai skor 1=Sangat tidak suka; $2=$ Tidak suka; $3=$ Agak tidak suka; $4=$ Netral; $5=$ =Agak suka; $6=$ Suka;

$7=$ Sangat suka.

**Nilai skor $1=$ sangat keras, $2=$ Tidak keras; $3=$ Agak tidak keras; $4=$ Netral; $5=$ Agak halus; $6=$ halus; 7

sangat halus

***Nilai skor $1=$ sangat tidak lengket, $2=$ Tidak lengket; $3=$ Agak tidak lengket; $4=$ Netral;

$5=$ Agak lengket; $6=$ lengket; 7 sangat lengket

****Huruf yang berbeda di sebelah angka pada kolom yang sama menunjukan perbedaan nyata $(\mathrm{P}<0,05)$

\section{Penerimaan Warna, Flavor, dan Keseluruhan Mie Kering}

Warna merupakan salah satu atribut mutu yang berperan penting dalam menarik perhatian konsumen terhadap suatu produk pangan (Winarno, 2009). Data pada Tabel 3 menunjukkan bahwa tingkat kesukaan panelis terhadap warna mie kering yang dihasilkan bervariasi dari 3,9-6,4 (agak tidak suka sampai sangat suka). Hasil sidik ragam memperlihatkan bahwa semua penambahan tepung ubi jalar dan tepung kedelai memberikan pengaruh yang sangat nyata terhadap penerimaan warna mie kering. Hasil uji lanjut Duncan pada tingkat kepercayaan 95\% dari setiap perlakuan tidak menunjukan adanya perbedaan nyata dengan kontrol, kecuali F2 (10\% tepung ubi jalar tanpa tepung kedelai) paling disukai. Penambahan tepung ubi jalar $10 \% \quad$ (F2) dapat meningkatkan penerimaan panelis terhadap warna mie kontrol, dengan tertinggi skor 6,4. Sedangkan 
penambahan tepung kedelai pada kadar 5\% dan $10 \%$, cenderung menurun tingkat penerimaan terhadap warna, dimana masingmasing skor rata-rata 4,3 dan 4,0 (Tabel 3).

Penggunaan tepung ubi jalar menghasilkan mie dengan wana kuning yang merata sehingga menghasilkan warna produk yang disukai, tetapi tepung kedelai menghasilkan bintik-bintik berwana coklat muda pada keseluruhan mie. Adanya bintik tersebut dapat berpengaruh merugikan terhadap penerimaan panelis dimana panelis beranggapan bahwa adanya bintik coklat muda tersebut tidak biasanya, disamping itu intensitas kecerahan dan warna kuning mie dengan penambahan tepung kedelai lebih rendah sehingga menurunkan kesukaan panelis.

Data pada Tabel 3 memperlihatkan bahwa penerimaan panelis terhadap flavor mie kering yang dihasilkan bervariasi dari 4,8-6,1 (netral sampai sangat suka), yang dipengaruhi konsentrasi tepung ubi jalar dan kedelai yang ditambahkan. Hasil sidik ragam memperlihatkan bahwa semua perlakuan berpengaruh sangat nyata terhadap kesukaan panelis terhadap flavor mie kering yang dihasilkan. Hasil uji lanjut Duncan pada tingkat kepercayaan 95\% memperlihatkan bahwa penambahan $10 \%$ tepung ubi jalar (F1) dan penambahan tepung kedelai 5\% (F2) tidak berbeda dengan kontrol (F0), tetapi pada penambahan $10 \%$ tepung kedelai (F3) menghasilkan aroma yang kurang disukai panelis sehingga menurunkan skor penerimaan panelis.

Dari data pada Tabel 3 memperlihatkan pula bahwa tepung ubi jalar cenderung meningkatkan penerimaan flavor; sedangkan peningkatan kadar tepung kedelai cenderung menurunkan tingkat penerimaan flavor mie. Rendahnya kesukaan panelias terhadap aroma kedelai diduga dipengaruhi oleh adanya aroma langu dari kedelai walau dalam intensitas yang rendah. Aroma langu dapat disebabkan oleh adanya aktivitas enzim lipoksidase (Winarno, 2009).

Penerimaan secara keseluruhan terhadap mie kering memiliki skor yang bervariasi antara 4,57-6,40 (netral-sangat suka), dimana yang terendah pada F3 dan yang tertinggi pada F1 (Tabel 3). Hasil sidik ragam memperlihatkan bahwa semua perlakuan berpengaruh sangat nyata terhadap kesukaan panelis terhadap penerimaan secara keseluruhan mie kering yang dihasilkan. Hasil uji lanjut Duncan pada tingkat kepercayaan 95\% menunjukkan bahwa bahwa F1 (penambahan $10 \%$ tepung ubi jalar) dengan skor tertinggi paling disukai dan berbeda nyata dengan semua perlakuan, namun penambahan tepung kedelai $5 \%(\mathrm{~F} 2)$ dan $10 \%$ (F3) tidak dengan skor penerimaan panelis masingmasing 5 (agak suka) dan 4,7 (antara biasa/netral dan agak suka). Penerimaan keseluruhan dilaporkan menurun ketika tepung jagung, isolat protein jagung dan produk kedelai ditambahkan pada pasta yang dibuat dengan semolina atau tepung gandum $(\mathrm{Wu}$ dkk., 1987).

\section{Intensitas Tekstur}

Tekstur bersifat kompleks dan terkait dengan struktur bahan pangan, untuk produk mie (pasta) setelah direhidrasi diinginkan tekstur yang halus (tidak keras) dan tidak lengket saat dikonsumsi (Astawan, 2003). Data pada Tabel 3 memperlihatkan kehalusan mie yang dihasilkan bervariasi dengan skor berkisar 3,7-6,0 (agak tidak lengket-lengket). Hasil analisis ragam yang dilakukan menunjukkan bahwa penambahan tepung ubi jalar dan kedelai yang diberikan berpengaruh sangat nyata terhadap kehalusan mie kering yang dihasilkan. Hasil uji lanjut Duncan pada tingkat kepercayaan 95\% menunjukkan bahwa pelakuan dengan penambahan $10 \%$ tepung ubi jalar tanpa kedelai (F2) memberikan kehalusan dengan nilai skor rata-rata 5,7 (antara agak halus sampai halus) tidak berbeda nyata dengan skor mie kontrol (F0). Sedangkan pada $10 \%$ tepung ubi jalar dengan 5\% (F2) dan 10\% (F3) tepung kedelai masing-masing memberikan skor rata-rata 4,3 (antara biasa/netral sampai agak halus) dan 3,7 (antara agak keras sampai biasa/netral). Bahnassey dan Khan (1986) melaporkan bahwa tepung dari legum atau kedelai bebas lemak meningkatkan kekuatan dari pasta semolina. Peningkatan kekuatan pasta ini diduga akibat terbentuknya jaringan protein yang kuat pada bahan yang kandungan proteinnya tinggi, dan juga karena tingginya kandungan serat kasar pada tepung kedelai yang difortifikasi pada mie kering.

Produk mie yang diharapkan memiliki intensitas kelengketan yang rendah (tidak lengket) saat dikonsumsi dalam mulut. Tabel 3 memperlihatkan kelengkatan mie yang dihasilkan bervariasi dengan skor berkisar 4,3- 
5,3 (agak tidak lengket-lengket). Hasil analisis ragam yang dilakukan menunjukkan bahwa perlakuan berpengaruh nyata terhadap tingkat kelengketan mie yang dihasilkan. Namun hasil uji lanjut Duncan pada tingkat kepercayaan 95\% tidak menunjukkan adanya perbedaan yang nyata antar perlakuan terhadap tingkat kelengketannya. Terdapat kecenderungan bahwa pelakuan penambahan $10 \%$ tepung ubijalar-tanpa kedelai dapat meningkatkan intensitas kelengketan mie yang dihasilkan. Sedangkan penambahan tepung kedelai pada level 5\% dan 10\% dengan 10\% tepung ubijalar lebih meningkatkan kelengketan mie, yang memberikan skor masing-masing 5,14 dan 5,28, yaitu antara agak tidak lengket sampai tidak lengket.

\section{KESIMPULAN}

Penggunaan tepung ubi jalar kuning $10 \%$ memberikan kontribusi yang lebih baik terhadap warna mie kering menjadi lebih kuning dan sifat sensori mie kering yang terdiri dari warna, flavor, penerimaan secara keseluruhan, sedangkan intensitas kehalusan dan kelengketan tidak berbeda nyata dengan control (mie 100\% terigu). Penambahan dan peningkatan konsentrasi tepung kedelai 5\% dan $10 \%$ pada formula dapat meningkatkan cooking loss dan menurunkan kecerahan warna serta sifat sensori mie kering yang dihasilkan.

\section{DAFTAR PUSTAKA}

Astawan, M., (2003), Membuat Mie dan Bihun. Penebar Swadaya. Jakarta.

Bahnassey, Y. dan Khan, K., (1986), Fortification of sphafetti with edible legumes. II. Rheological, processing and quality evaluation studies. Cereal Chemistry, 63(3), pp. 216-219.

Collins, J.L. dan Pangloli, P., (1997). Chemical, Physical and Sensory Atribes of Noodles with added Sweet potato and Soy Flour. Journal of Food Science, 62:3, pp. 622-625.

Hidayat, F., Anum, F., Dewi, E, dan Sholihati, (2019), Kajian penambahan pasta umbi bit merah (Beta vulgaris L) dan tepung kacang hijau (Phaseolus radiatus L) dalam pembuatan roll cookies. Jurnal Rona Teknik Pertanian, 12 (1), pp. 1-11.
Juanda, D. dan Cahyono, B., (2000), Ubi Jalar Budidaya dan Analisis Usaha Tani. Kanisius. Yogyakarta.

Metres, C., Collona, P., and Buleon, A., (1988), Characteristics of Strarch Network Within Flour Noodles and Mung Bean Starch Vermicelli. Journal of Food Science, 53, pp. 1809-1812.

Muhandri, T., (2012), Mekanisme Proses Pembuatan Mi Berbahan Baku Jagung. Buletin Teknologi PascaPanen Pertanian, 8(2), pp. 70-79.

Mulyadi, A. F, Wignyanto, Anita Novalia Budiarti, (2013), Pembuatan mie kering kemangi (Ocimum sanctum L.) dengan bahan dasar tepung terigu dan tepung Mocaf (Modified Cassava Flour) (Kajian Jenis Perlakuan Dan Konsentrasi Kemangi). Prosiding Seminar Nasional "Konsumsi pangan sehat dengan gizi seimbang menuju tubuh sehat bebas penyakit" Fakultas Teknologi PertanianUniversitas Gajah Mada, Yogyakarta.

Nielsen, M. A., Sumner, A.K., dan Whalley L.L., (1980), Fortification of pasta with pea four and air-clasified pea protein concentrate. Cereal Chemistry. 57, pp. 203 - 206.

Pagani, M.A., (1985), Pasta Products from Non Conventional Raw Materials. In: Mercier and C. Contarelli (Ed) 1985. Pasta and Extrusion Cooked Foods. Processing of an International Symposium Held in Millan. Italy.

Rasper, V.F., dan de Man, J. M., (1980), Effects of granule size of substituted starches on the rheological character of composite doughs. Cereal Chemistry, 57, pp. 331-340.

Setyaningsih, D, Apriyantono, A, dan Sari, MP., (2010), Analisa Sensori Industri Pangan dan Agro. IPB Press, Bogor.

Widaningrum, Widowati, S., dan Soekarto, S.T., (2005). Pengayaan tepung kedelai pada pembuatan mie basah dengan bahan baku tepung terigu yang disubstitusi tepung garut. Jurnal Pascapanen, 2(1), pp 41-48.

Winarno, F. G., (2009), Kimia pangan dan gizi. PT.Gramedia Pustaka Utama. Jakarta.

Wu, Y. V., Young, V. L., Warner, K., dan Walter, G. N., (1987), Evaluation of Sphagetti suplemented with Corn 
Agritechnology 2(2) 2019

ISSN: 2615-885X (cetak), 2620-4738 (online) DOI: https://doi.org/10.51310/agritechnology.v2i2.46

distiller dried grains. Cereal Chemical.

64 (6), pp. 434-436. 